\title{
The Relationship between Relationship Investment, Relationship Quality, and Attachment Styles
}

\author{
Hui-Chen Chang \\ National Taipei University \\ E-Mail: cjenny@gm.ntpu.edu.tw \\ Lin-Ju Cheng \\ St. John's University \\ E-Mail: clrvicky@mail.sju.edu.tw \\ Yi-Ching Tsai* \\ Shih Chien University \\ E-Mail: proworld@ms24.hinet.net \\ Hung-Chun Lai \\ National Taipei University \\ E-Mail: ninalai0913@gmail.com
}

\begin{abstract}
This study examines the impact of relationship investment on relationship quality in dental technology. In addition, it explores the moderating effects between relationship investment and relationship quality by using customer attachment to different dentists' styles. The study collects 202 questionnaires from dentists in Taiwan. This study uses hierarchy regression analysis to test hypotheses. The empirical results show that 1) relationship investment has a significantly positive effect on relationship quality; and 2) that customer attachment has a moderating effect on relationship investment and relationship quality. Both attachment anxiety and attachment avoidance have significantly negative effects on relationship quality. However, only attachment anxiety has a significantly moderating effect on relationship investment and relationship quality.
\end{abstract}

Keywords: Relationship Investment, Relationship Quality, Dental Technology, Attachment Style

\footnotetext{
${ }^{*}$ Corresponding author
} 


\section{INTRODUCTION}

With the internet, consumers can obtain product information faster and more easily. Therefore, the information provided by the manufacturer is no longer the only factor that influences consumers' purchasing decisions. One important factor is the interaction between consumer's social network. The situation resulted in marketing becoming more consumer oriented than before. If firms want to attract customers and encourage them to make purchases, they need to put the customer first. Moreover, they need to emphasize strategic and holistic marketing (Kotler, 2012).

Holistic marketing consists of internal marketing, social responsibility, integration marketing and relationship marketing. Relationship marketing comes with mutual benefits. This practice is consistent with certain marketing trends. If the business is to build relationships with customers, every interaction with a customer is an opportunity to form a relationship. This process includes the interaction of products, services, knowledge, information and other contents. The interaction would strengthen the long-term relationship. The interaction also has an interpersonal character; it is a personalizing process that allows consumers to recognize the mutual benefit from the firm. Besides the perceptions of products and services, mutual benefit is evaluated in terms of satisfaction with the relationship. The mutual benefit can increase the customer's repurchase intention (Kolter, 2012).

Paulseen (2009) noted that the heterogeneity of relationship behavior during the interactive process affects repurchase intention. Previous studies have shown that different relationships require different relationship investment programs (Bendapudi and Berry, 1997; Paulssen, 2009; Wulf, Odekerken-Schröder, and Iacobucci, 2001). They also found that different kinds of customers prefer different relationship investment programs. Psychological theory used people's attachment style to explain individual preferences in interpersonal networks. In recent relationship marketing studies, some scholars have applied this theory to explore the influence on different relationship constructs.

This study applies psychological theory to the dental technology industry. Because firms in Taiwan's dental technology industry are SME-based, they face a highly competitive and buyer-oriented environment. Dental technology firms need to use their marketing resources to gain a competitive advantage. They produce the customized dentures that the dental clinics want. In addition, they need the professional capabilities and skills to communicate with dental clinics. Therefore, the dental technology firm might build a stable relationship with the dental clinic after the dental clinic recognizes this denture service. It may establish a switching barrier. The 
dental technology firm needs to use marketing resources to form a stable relationship. This study uses the customer attachment style to explore the heterogeneity of relationship behavior. It also discusses different customer styles and different kinds of relationship investment.

\section{LITERATURE REVIEW}

\section{Relationship Investment}

Relationship marketing (RM) establishes mutually beneficial and long-term relationships in interaction with customers. Many firms invest in relationships to increase the customer's perceived value. This is described as relationship value (Ulaga and Eggert, 2005) in RM. Many firms invest heavily in different types of RM activities to ensure their competitive advantage. Increasing relationship value indicates that firms generate customer-seller bonds or offer benefits in the relationships development (Dagger and O'Brien, 2010; Palmatier, Gopalakrishna, and Houston, 2006). However, different RM investment activities may generate different efforts.

Relationship value is similar to customer value. The trade-off is between the benefits ("what you get") and the sacrifices ("what you give") in a market exchange (Ulaga and Eggert, 2005; Zeithaml, 1988). The concept of relationship value was formulated by Anderson, Jain, and Chintagunta (1992), and Ulaga and Eggert (2005). They defined relationship value as the economic, technical, service, and social benefits $s$ received in exchange for offerings and prices. It represents the relational dimensions, which are social and service benefits. Grönroos (1997, p. 412) identified two beneficial and two sacrificial dimensions. The dimensions were the determinants of the overall value perceived by the customer (Tzokas and Saren, 1999; Ulaga and Eggart, 2005). Little research has focused on relationship value. Gwinner, Gremmler, and Bitner (1998) identified three categories from customer-benefits-offered: confidence, social, and special treatment benefits.

A different perspective for identify relationship investment activities was customer-bonds-formed (Berry, 1995). It suggests that businesses build customer relationships by forming financial, social, and structural bonds (e.g., Berry, 1995; Berry and Parasuraman, 1991). Although these typologies use different criteria for group relationship investment, the outcomes remain consistent. The literature research in the relationship investment belongs to B2B context. Palmatier et al. (2006) adopted Berry's (1995) labels -- financial, social, and structural relationship marketing programs -- to explicate the impact of relationship marketing investments and other drivers on customer-specific return. They indicated that social relationship marketing in investments pays off handsomely but financial relationship marketing investments 
do not. Sweeney and Webb (2007) found that relationship investment improves relationship outcomes. They used relationship benefit as relationship investment construct. The categories of benefits were functional, social and psychological. Functional benefit affects commitment directly but psychological benefit and social benefit affect commitment indirectly. In this study, relationship investment extends beyond the relational bonds and benefits descriptors that are too often adopted in the literature.

\section{Relationship Quality}

In the B2B2B context, relationship quality reflects the intensity and assessment of the relationship between customers and firms. The quality contained that the customer's needs and expectations had reached received more satisfaction (Johnson, 1999). Thus, relationship quality was a measure of customer-perceived value (Naudé and Buttle, 2000; Woo and Ennew, 2004). Relationship quality had many constructs. Trust, satisfaction and commitment were the most common (Hutchinson, Wellington, Saad and Cox, 2011; Park and Kim, 2014; Rafiq, Fulford, and Lu, 2013). This study indicates that satisfaction and trust are two variables of relationship quality.

\section{Customer Attachment Style}

According to Mende and Bolton (2011), "An attachment style is the systematic pattern of relational expectations, needs, emotions, and social behaviors that results from the internalization of a particular history of attachment experiences." This interpretation was derived from the attachment theory and proposed by Bowlby (1969). He noted that the infants' interaction with their caregivers would affect their future relationships. According to the environment that the customer faces, the attachment style would form the systematic differences (Swaminathan, Stilley, and Ahluwalia, 2009). Further studies had found that other relationships led to similar attachment behaviors. (Ainsworth, 1989; Hazan and Shaver, 1987; Trinke and Bartholomew, 1997). Recent literature has distinguished the different styles. Brennan, Clark, and Shaver (1998) measure along two dimensions: anxiety and avoidance. The anxiety dimension is a person's view of self. The anxious person worries that the relationship partner could not immediately meet the demand. He also needs to be sure, or fears being rejected and abandoned. The avoidance dimension is a person's view of others. The avoidant person fears depending on partners and distrusts good relationships. He refuses to understand his partner (Mende, Bolton, and Bitner, 2013; Swaminathan et al., 2009). This method is a mainstream measure in recent studies. 
To develop a long-term relationship, customers considered reciprocity (Bendapudi and Berry, 1997; Paulssen, 2009; Wulf et al., 2001). However, the perception of reciprocity depends on the relationship. Some scholars explain the heterogeneity of relationship behavior in terms of attachment theory. Thomson and Johnson (2006) used students' attachment styles to understand the impact of satisfaction and commitment of individual and commercial behavior. They found that the assessment of the company or brand was influenced by attachment anxiety or avoidance; both were negative perceptions of reciprocity. Swaminathan et al. (2009) investigated how the student attachment styles moderated brand personality to affect brand selection and purchase possibilities. According to attachment styles for B2B customers, Paulssen (2009) indicated that customer attachment style would impact customers' satisfaction, trust and repurchase intention. Mende and Bolton's (2011) empirical results showed that low anxiety and avoidance scores would be more conducive to satisfaction, trust and emotional commitment. Mende et al. (2013) also disclosed the attachment styles would affect the preferences of close relationship and loyalty intentions.

This study defines two dimensions of customer attachment style. Customer attachment anxiety is the extent to which a customer worries that the firm might not be available in times of need. Such a customer has an excessive need for approval, and fears rejection and abandonment from this firm (Brennan et al., 1998; Thomson and Johnson, 2006). Customer attachment avoidance is the extent to which a customer distrusts the firm's goodwill. This customer is characterized by an excessive need for self-reliance, fears depending on the firm, and strives for emotional and cognitive distance (Brennan et al., 1998; Thomson and Johnson, 2006; Verbeke, Bagozzi and, van den Berg, 2014).

\section{METHODOLOGY}

\section{Research Framework}

The research framework is organized into three constructs: relationship investment, relationship quality, and customer attachment style. This study discusses the causal effect between relationship investment and relationship quality. In addition, it discusses the moderating effect of the customer attachment style between relationship investment and relationship quality (figure 1). 


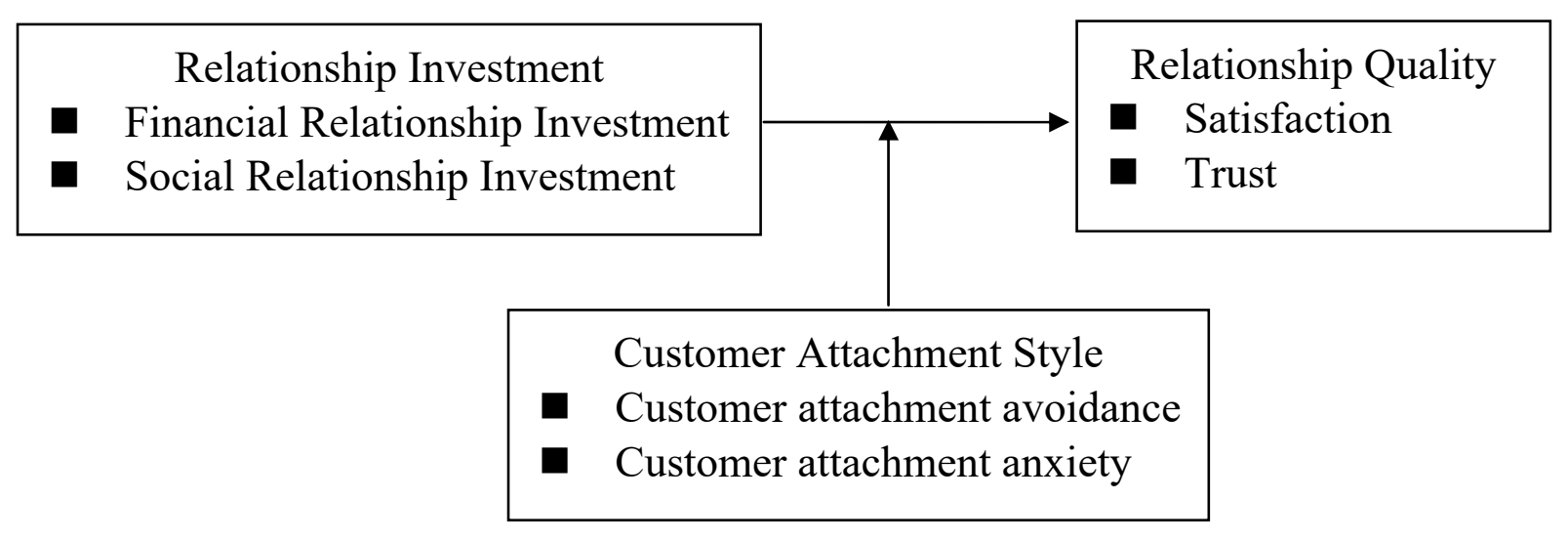

Figure 1 Research Framework

\section{Research Hypotheses}

The relationship investment consists of two dimensions: financial relationship investment and social relationship investment. The financial relationship investment refers to the direct economic benefits in exchange. The social relationship investment is the attempt to personalize the relationship and to convey special status. It includes social engagements, the perceptions of affinity, and individual service.

A review of the literature shown that financial and social relationship investment drives perceptions of satisfaction and trust (Bolton, Kannan, and Bramlett, 2000; Chih and Chang, 2006; Clark and Melancon, 2013; Gwinner et al., 1998; Park and Kim, 2014; Reynolds and Beatty, 1999). Dagger and O'Brien (2010) revealed that if service industries could offer financial benefit for their customers, it would have a positive impact on satisfaction, trust and commitment. Nath and Mukherjee's (2012) empirical results indicated that while banking combined financial investment with corporate strategy, it could increase customer satisfaction and trust. In this article, we posit that relationship investment has a positive effect on relationship quality. Accordingly, the following hypotheses are formulated:

$\mathbf{H}_{\mathbf{1}}$ : Financial relationship investment has a positive effect on satisfaction.

$\mathbf{H}_{\mathbf{1 b}}$ : Financial relationship investment has a positive effect on trust.

$\mathbf{H}_{2 \mathrm{a}}$ : Social relationship investment has a positive effect on satisfaction.

$\mathbf{H}_{2 \mathbf{b}}$ : Social relationship investment has a positive effect on trust.

In the B2B field, not all customers prefer close and informal personal contacts (Price and Amould, 1999). Researchers have noted that different relationship investments may be suitable for different styles of customer attachment (Mende and Bolton, 2011; Thomson and Johnson, 2006). Because people who score high on the 
avoidance dimension of attachment style may not expect social or emotional exchange (Thomson and Johnson, 2006). For these people, dealing with the firm through monetary exchange is better than sharing information (Barnes, 1997; Price and Amould, 1999). Customers who have problems forming interpersonal bonds are more likely to form financial ones. Thus, customers with attachment avoidance may seek out monetary exchange relationships. These customers also might be targeted by financial investment in a relationship (Mende and Bolton, 2011). People who score high on the anxiety dimension of attachment style may avoid adventure-seeking and risk-taking activities (Carnelley and Ruscher, 2000). However, anxious customers do not perceive their relationships as reciprocal because their self-defeating cycles prevent the development of the relationship (Thomson and Johnson, 2006). Mende and Bolton (2011) implied that customers who show low attachment anxiety and avoidance are receptive to relationship building. They suggested the primary candidate will invest in a social relationship. However, customers with attachment anxiety are worried that the relationship partner cannot immediately meet the demand. They need reassurance that they will not be rejected and abandoned. We posit that customers with high levels of attachment anxiety might be interested in a social relationship investment.

Gaynor (1994) indicated that physician service is a professional service which is heterogeneous and unsold. Based on these attributes, each physician has a monopoly. Lagace, Dahlstromb and Gassenheimer (1991) revealed that the relationship between the pharmaceutical salesperson and physician could affect trust and satisfaction. Our sample consists of dentists, therefore, this study examines how customer attachment avoidance and anxiety moderate the relationship investment to relationship quality. Accordingly, the following hypotheses are formulated:

$\mathrm{H}_{3 \mathrm{a}}$ : Customer attachment avoidance has a positive moderating effect on the relationship of financial investment to satisfaction.

$\mathrm{H}_{3 \mathrm{~b}}$ : Customer attachment avoidance has a positive moderating effect on the relationship of financial investment to trust.

$\mathrm{H}_{4 \mathrm{a}}$ : Customer attachment anxiety has a positive moderating effect on the relationship of social investment to satisfaction.

$\mathrm{H}_{4 \mathrm{~b}}$ : Customer attachment anxiety has a positive moderating effect on the relationship of social investment to trust.

\section{Definition and Measurement Items}

All of the questionnaire items were adapted from the literature. Relationship investment included two dimensions: financial and social relationship investment. 
Both were measured with items from previous studies (Berry, 1995; Gwinner et al., 1998; Palmatier et al., 2006; Sweeney and Webb, 2007). Relationship quality reflected the intensity and overall assessment of relationship between a customer and the firm. Satisfaction and trust were two most common constructs in relationship quality (Hutchinson et al., 2011). Satisfaction was measured with items from Oliver (2014), Hennig-Thurau, Gwinner, and Gremler (2002), and Reynolds and Beatty (1999). Trust was measured with items from Morgan and Hunt (1994), Doney and Cannon (1997). Customer attachment style had two dimensions -- customer attachment anxiety and customer attachment avoidance. Both were measured with items from Mende and Bolton (2011). All variables of questionnaire in our study were measured on seven-point Likert scales, where 1 reflected "strongly disagree" and 7 reflected "strongly agree."

\section{Sampling and Data Collecting}

This study investigates Taiwan's dental technology industry, and tests the relationship among relationship investment, relationship quality and customer attachment style. Dentists are the target market of dental technology firms. However, the patients wear the dentures. In other words, the dentists are in a surrogate-mediated shopper role; they help their patients to make the decision. The final consumers (patients) are not symmetrical about the information available on the product itself (Kolter, 2012). The final consumers trust the dentists. (Parasuraman, Zeithaml, and Berry, 1985). Thus, the samples were the Taiwan's dentists. The researcher collected 250 samples through online and hard copy, from which 202 useful questionnaires were obtained, yielding an effective response rate of 80.8 percent.

This study used descriptive statistics, reliability and validity to analyze the results from the questionnaire. Hierarchy regression analysis was used to test the hypotheses.

Among the responses received, males accounted for 65.3 percent, and 35.6 percent of the total respondents were under 30 years of age. Location is focused on northern, included Taipei, New Taipei, Keelung and so on, account for 53 percent.

\section{RESULTS}

\section{Reliability and Validity}

All Cronbach's $\alpha$ of this study were higher than 0.8, indicating high reliability. All items factor loadings were higher than 0.5 (Hair, Black, Babin, Anderson, and Tatham, 2006), composite reliability (CR) was more than 0.7 (Chin, 1998). This study demonstrated adequate internal consistency. 
Table 1 Reliability and Validity Analysis

\begin{tabular}{|c|c|c|c|c|c|}
\hline Constructs & Items & Factor Loading & Cronbach's $\alpha$ & $\mathrm{CR}$ & AVE \\
\hline \multirow{3}{*}{$\begin{array}{l}\text { Financial Relationship } \\
\text { Investment (FRI) }\end{array}$} & FRI1 & 0.89 & \multirow{3}{*}{0.947} & \multirow{3}{*}{0.948} & \multirow{3}{*}{0.860} \\
\hline & FRI2 & 0.96 & & & \\
\hline & FRI3 & 0.93 & & & \\
\hline \multirow{6}{*}{$\begin{array}{l}\text { Social Relationship Investment } \\
\text { (SRI) }\end{array}$} & SRI1 & 0.85 & \multirow{6}{*}{0.877} & \multirow{6}{*}{0.749} & \multirow{6}{*}{0.561} \\
\hline & SRI2 & 0.80 & & & \\
\hline & SRI3 & 0.81 & & & \\
\hline & SRI4 & 0.86 & & & \\
\hline & SRI5 & 0.60 & & & \\
\hline & SRI6 & 0.50 & & & \\
\hline \multirow{4}{*}{ Satisfaction (SA) } & SA1 & 0.94 & \multirow{4}{*}{0.955} & \multirow{4}{*}{0.955} & \multirow{4}{*}{0.824} \\
\hline & $\mathrm{SA} 2$ & 0.88 & & & \\
\hline & SA3 & 0.91 & & & \\
\hline & SA4 & 0.94 & & & \\
\hline \multirow{6}{*}{ Trust (TR) } & TR1 & 0.91 & \multirow{6}{*}{0.961} & \multirow{6}{*}{0.962} & \multirow{6}{*}{0.808} \\
\hline & TR2 & 0.87 & & & \\
\hline & TR3 & 0.87 & & & \\
\hline & TR4 & 0.93 & & & \\
\hline & TR5 & 0.89 & & & \\
\hline & TR6 & 0.92 & & & \\
\hline \multirow{2}{*}{$\begin{array}{l}\text { Customer Attachment } \\
\text { Avoidance (CAV) }\end{array}$} & AV1 & 0.73 & \multirow{4}{*}{0.911} & \multirow{4}{*}{0.919} & \multirow{4}{*}{0.741} \\
\hline & $\mathrm{AV} 2$ & 0.89 & & & \\
\hline \multirow{6}{*}{$\begin{array}{l}\text { Customer Attachment Anxiety } \\
(\mathrm{CAX})\end{array}$} & AV3 & 0.92 & & & \\
\hline & AV4 & 0.89 & & & \\
\hline & AX1 & 0.59 & \multirow{4}{*}{0.866} & \multirow{4}{*}{0.872} & \multirow{4}{*}{0.635} \\
\hline & $\mathrm{AX} 2$ & 0.82 & & & \\
\hline & AX3 & 0.93 & & & \\
\hline & $\mathrm{AX} 4$ & 0.81 & & & \\
\hline
\end{tabular}

This study used confirmatory factor analysis (CFA) to measure convergent validity. All items factor loadings were higher than 0.4; this study was convergent. Then, we used average variance extracted (AVE) to measure discriminant validity. AVE square root should be higher than the correlation coefficients for each pair of constructs (Fornell and Larcker, 1981). All AVE square roots were higher than the correlation coefficients for each pair of constructs, except TR*SA correlation coefficients (0.901), demonstrating discriminant validity. The results of reliability, 
validity analysis, AVE square root and correlation matrix are shown in tables 1 and 2.

Table 2 AVE Square Root and Correlation Matrix

\begin{tabular}{cllllll}
\hline Constructs & FRI & SRI & SA & TR & CAV & CAX \\
\hline FRI & $\mathbf{0 . 9 2 7}$ & & & & & \\
SRI & $0.665 * * *$ & $\mathbf{0 . 7 4 9}$ & & & & \\
SA & $0.137 * * *$ & $0.346^{* * *}$ & $\mathbf{0 . 9 0 8}$ & & & \\
TR & $0.134 * * *$ & $0.320^{* * *}$ & $0.901 * * *$ & $\mathbf{0 . 8 9 9}$ & & \\
CAV & $0.281 * * *$ & $0.409 * * *$ & $0.568 * * *$ & $0.564 * * *$ & $\mathbf{0 . 8 6 1}$ & \\
CAX & $0.395^{* * *}$ & $0.187 * * *$ & $-0.289 * * *$ & $-0.301 * * *$ & 0.006 & $\mathbf{0 . 7 9 7}$ \\
\hline
\end{tabular}

Note: 1.Diagonal are AVE Square Root, the others are correlation coefficients.

2. $* \mathrm{p}<0.05, * * \mathrm{p}<0.01, * * * \mathrm{p}<0.001$.

\section{Hypotheses Testing}

This study used hierarchical regression analysis to test hypotheses, and the results are shown in tables 3 and $4 . M_{1}$ and $M_{7}$ tested the impact of financial relationship investment on satisfaction $(\beta=0.090)$ and trust $(\beta=0.125)$. The financial relationship investment had a positive but not significant effect on satisfaction and trust, so $\mathrm{H}_{1 \mathrm{a}}$ and $\mathrm{H}_{1 \mathrm{~b}}$ were not supported. $\mathrm{M}_{4}$ and $\mathrm{M}_{10}$ tested the impact of social relationship investment on satisfaction $(\beta=0.379, \mathrm{p}<0.01)$ and trust $(\beta=0.397, \mathrm{p}<0.01)$. The results showed that social relationship investment had a positive effect on satisfaction and trust, supporting $\mathrm{H}_{2 \mathrm{a}}$ and $\mathrm{H}_{2 \mathrm{~b}}$. Afterwards, this study tested the moderate effect of the customer attachment avoidance. $\mathrm{M}_{3}$ and $\mathrm{M}_{9}$ tested the impact of attachment avoidance moderating financial relationship investment on satisfaction $(\beta=0.122)$ and trust $(\beta=0.104)$. The customer attachment avoidance had a positive no significant moderating effect, $\mathrm{H}_{3 \mathrm{a}}$ and $\mathrm{H}_{3 \mathrm{~b}}$ were not supported. Finally, $\mathrm{M}_{6}$ and $\mathrm{M}_{12}$ tested the impact of attachment anxiety moderating social relationship investment on satisfaction $(\beta=0.169)$ and trust $(\beta=0.177)$. The results indicated that customer attachment anxiety had a positive but not significant moderating effect, not supporting $\mathrm{H}_{4 \mathrm{a}}$ and $\mathrm{H}_{4 \mathrm{~b}}$. 
Table 3 Hypotheses Results (Dependent Variable: Satisfaction)

\begin{tabular}{ccccccc}
\hline Constructs & $\mathrm{M}_{1}$ & $\mathrm{M}_{2}$ & $\mathrm{M}_{3}$ & $\mathrm{M}_{4}$ & $\mathrm{M}_{5}$ & $\mathrm{M}_{6}$ \\
\hline Intercept & 5.254 & 1.992 & 1.766 & 3.960 & 4.795 & 5.394 \\
FRI & 0.090 & -0.152 & $-0.204^{*}$ & & & \\
SRI & & & & $0.379^{* *}$ & $0.439 * *$ & $0.425^{* * *}$ \\
CAV & & $0.806^{* * *}$ & $0.875^{* *}$ & & & \\
CAX & & & & & $-0.295^{* *}$ & $-0.451^{* * *}$ \\
FRI*CAV & & & 0.122 & & & \\
SRI*CAX & & & & & & 0.169 \\
F-value & 0.734 & 37.649 & 28.173 & 9.938 & 11.093 & 9.231 \\
$\mathrm{R}^{2}$ & 0.012 & 0.552 & 0.585 & 0.138 & 0.267 & 0.316 \\
Adj $\mathrm{R}^{2}$ & 0.004 & 0.538 & 0.564 & 0.124 & 0.243 & 0.282 \\
\hline
\end{tabular}

Note: ${ }^{*} \mathrm{p}<0.05, * * \mathrm{p}<0.01, * * * \mathrm{p}<0.001$.

Table 4 Hypotheses Results (Dependent Variable: Trust)

\begin{tabular}{ccccccc}
\hline Constructs & $\mathrm{M}_{7}$ & $\mathrm{M}_{8}$ & $\mathrm{M}_{9}$ & $\mathrm{M}_{10}$ & $\mathrm{M}_{11}$ & $\mathrm{M}_{12}$ \\
\hline Intercept & 5.196 & 1.959 & 1.767 & 3.952 & 4.691 & 5.321 \\
FRI & 0.125 & 0.799 & $-0.159^{*}$ & & & \\
SRI & & & & $0.397^{* *}$ & $0.450^{* * *}$ & $0.436^{* * *}$ \\
CAV & & $-0.114^{* * *}$ & $0.859^{* * *}$ & & & \\
CAX & & & & & $-0.261^{* *}$ & $-0.425^{* * *}$ \\
FRI*CAV & & & 0.104 & & & \\
SRI*CAX & & & & & & 0.177 \\
F-value & 1.527 & 42.886 & 31.174 & 11.782 & 11.024 & 9.521 \\
$\mathrm{R}^{2}$ & 0.024 & 0.584 & 0.609 & 0.160 & 0.265 & 0.323 \\
Adj $\mathrm{R}^{2}$ & 0.008 & 0.571 & 0.590 & 0.146 & 0.241 & 0.289 \\
\hline
\end{tabular}

Note: $* \mathrm{p}<0.05, * * \mathrm{p}<0.01, * * * \mathrm{p}<0.001$ 


\section{CONCLUSION}

The results of hypotheses testing are shown in table 5.

Table 5 Results of Hypotheses Testing

\begin{tabular}{|c|c|}
\hline Hypothesis & Results \\
\hline $\begin{array}{l}\mathrm{H}_{1 \mathrm{a}} \text { : Financial relationship investment has a positive effect on } \\
\text { satisfaction. }\end{array}$ & Supported \\
\hline $\mathrm{H}_{1 b}$ : Financial relationship investment has a positive effect on trust. & Not Supported \\
\hline $\mathrm{H}_{2 \mathrm{a}}$ : Social relationship investment has a positive effect on satisfaction. & Supported \\
\hline $\mathrm{H}_{2 \mathrm{~b}}$ : Social relationship investment has a positive effect on trust. & Supported \\
\hline $\begin{array}{l}\mathrm{H}_{3 \mathrm{a}} \text { : Customer attachment avoidance has a positive moderating effect on } \\
\text { the relationship of financial investment to satisfaction. }\end{array}$ & Not Supported \\
\hline $\begin{array}{l}\mathrm{H}_{3 \mathrm{~b}} \text { : Customer attachment avoidance has a positive moderating effect on } \\
\text { the relationship of financial investment to trust. }\end{array}$ & Not Supported \\
\hline $\begin{array}{l}\mathrm{H}_{4 \mathrm{a}} \text { : Customer attachment anxiety has a positive moderating effect on } \\
\text { the relationship of social investment to satisfaction. }\end{array}$ & Not Supported \\
\hline $\begin{array}{l}\mathrm{H}_{4 \mathrm{~b}} \text { : Customer attachment anxiety has a positive moderating effect on } \\
\text { the relationship of social investment to trust. }\end{array}$ & Not Supported \\
\hline
\end{tabular}
Note: ${ }^{*} \mathrm{p}<0.05, * * \mathrm{p}<0.01, * * * \mathrm{p}<0.001$.

Our empirical results show that financial relationship investment has a positive effect on satisfaction, supporting $\mathrm{H}_{1 \mathrm{a}}$. It means that if the dental clinics could offer more financial options to the customers, it can increase the customer's satisfaction. The result concurs with the findings of Bolton et al. (2000), Dagger and O'Brien (2010), Gwinner et al. (1998), Reynolds and Beatty (1999). Financial investment has no significant positive effect on trust, not supporting $\mathrm{H}_{1 \mathrm{~b}}$. The study proposes that the dental clinic spends a lot of money on equipment, but the financial options the dental technology firm offers cannot gain the dental clinic's trust, leading to the empirical results that financial investment has no significant positive on trust.

In addition, social investment has a positive effect on satisfaction and trust, supporting $\mathrm{H}_{2 \mathrm{a}}$ and $\mathrm{H}_{2 \mathrm{~b}}$. The result confirms the findings of Bolton et al. (2000), Dagger and O'Brien (2010), Gwinner et al. (1998), Reynolds and Beatty (1999). It indicates that the dental technology firms should share more resources and information with the dental clinics to create a long-term relationship, it could increase customer satisfaction and trust.

Finally, the study investigates the moderate effects of customer attachment avoidance and customer attachment anxiety. The empirical results show that customer 
attachment avoidance has a positive but not significant moderating effect on the relationship of financial investment to satisfaction and trust, not supporting $\mathrm{H}_{3 \mathrm{a}}$ and $\mathrm{H}_{3 \mathrm{~b}}$. In addition, customer attachment anxiety has a positive but not significant moderating effect on the relationship of financial investment to satisfaction and trust, $\mathrm{H}_{4 \mathrm{a}}$ and $\mathrm{H}_{4 \mathrm{~b}}$ are not supported.

\section{Managerial Implications}

In this study, we posit that relationship investment could increase the score of relationship quality. Prior research had not examined this effect on the relationship between dental technology firms and dental clinics. We use this model to examine Taiwan's dental technology industry, because most firms are SMEs-based. This study finds that financial investment and social relationship investment have a positive effect on relationship quality. The results show that relationship investment positively affects relationship quality. Social relationship investment is more significant than financial investment. The results suggest that the dental technology firm can focus on social relationship investment. The dental technology firm can participate in social engagements, such as conference workshops, meals, and sport events. These events may build the social network more quickly, increase the chance of interaction, and the perception of affinity, like friendship. They can also provide faster and customized service to the dental clinics in order to create long-term relationships and trust.

This study posits that customer attachment style moderates the association between relationship investment and relationship quality. Prior research had discussed the effect between customer attachment style and relationship quality. The dental clinic is a strong buyer and the power between the dental clinic and the dental technology firm is not symmetrical. If a dental technology firm could target the preference of the dental clinic, that firm can use the right kind of relationship investment. In addition, the firm could use marketing resources to create a long-term relationship. We explore customer attachment anxiety and customer attachment avoidance to moderate the association between relationship investment and relationship quality. The results show that customer attachment avoidance moderates financial relationship investment to relationship quality. When attachment avoidance increases, the negative effect between financial relationship investment and relationship quality becomes stronger (more negative). Customer attachment anxiety moderates the social relationship investment to relationship quality. When attachment anxiety increases, the positive effect between social relationship investment and relationship quality becomes stronger (more positive). We suggest that the dental technology firm could focus on social relationship investment to the dental clinic in 
customer anxiety style. Because anxious customers do not perceive their relationships as reciprocal, their self-defeating cycles prevent to develop more close relationships. This study suggests that the dental technology uses continuous social relationship investment to keep relationships with anxious customers. It might lower the anxious customer worries in avoiding adventure and risk.

\section{Limitations}

This study has the following limitations. This model did not consider separating the customer attachment styles. A worthy direction for future research would be to address the relationship between different customer attachment styles to relationship quality. In addition, we did not study the influence on other kinds of relationship investment to the relationship quality. Future research could examine more moderation on the association between important relationship constructs.

\section{REFERENCES}

Ainsworth, M. S. (1989). Attachments beyond infancy. American Psychologist, 44(4), 709-716. http://dx.doi.org/10.1037/0003-066X.44.4.709

Anderson, J. C., Jain, D. C., \& Chintagunta, P. K. (1992). Customer value assessment in business markets: A state-of-practice study. Journal of Business-to-Business Marketing, 1(1), 3-29. http://dx.doi.org/10.1300/J033v01n01_02

Barnes, J. G. (1997). Closeness, strength, and satisfaction: Examining the nature of relationships between providers of financial services and their retail customers. $\begin{array}{lll}\text { Psychology } \quad \text { \& } \quad \text { Marketing, } & \text { 14(8), }\end{array}$ http://dx.doi.org/10.1002/(SICI)1520-6793(199712)14:8\%3C765::AID-MAR3\% 3E3.0.CO;2-C

Bendapudi, N., \& Berry, L. L. (1997). Customers' motivations for maintaining relationships with service providers. Journal of Retailing, 73(1), 15-37. http://dx.doi.org/10.1016/S0022-4359(97)90013-0

Berry, L. L. (1995). Relationship marketing of Services-Growing interest, emerging perspectives. Journal of the Academy of Marketing Science, 23(4), 236-245. http://dx.doi.org/10.1177/009207039502300402

Berry, L. L., \& Parasuraman, A. (1991). Marketing services: Competing through quality. New York, NY: Free Press.

Bolton, R. N., Kannan, P. K., \& Bramlett, M. D. (2000). Implications of loyalty program membership and service experiences for customer retention and value. Journal of the Academy of Marketing Science, 28(1), 95-108. http://dx.doi.org/10.1177/0092070300281009 
Bowlby, J. (1969). Attachment and loss v. 3 (Vol. 1). Random House. Furman, W., \& Buhrmester, D. (2009). Methods and measures: The network of relationships inventory: Behavioral systems version. International Journal of Behavioral Development, 33, 470-478.

Brennan, K. A., Clark, C. L., \& Shaver, P. R. (1998). Self-report measurement of adult attachment: An integrative overview. In J. A. Simpson \& W. S. Rholes (Eds.) Attachment theory and close relationships (pp. 46-76). New York: Guilford Press.

Carnelley, K. B., \& Ruscher, J. B. (2000). Adult attachment and exploratory behavior in leisure. Journal of Social Behavior and Personality, 15(2), 153-165.

Chih, W. H., \& Chang, S. H. (2006). The store's relationship investment and satisfaction: A multilevel moderating effect of loneliness. NTU Management Review, 16(2), 1-28.

Chin, W. (1998). Issues and opinion on structural equation modeling. MIS Quarterly, 22(1), 7-16.

Clark, M., \& Melancon, J. (2013). The influence of social media investment on relational outcomes: A relationship marketing perspective. International Journal of Marketing Studies, 5(4), 132-142. http://dx.doi.org/10.5539/ijms.v5n4p132

Dagger, T. S., \& O'Brien, T. K. (2010). Does experience matter? Differences in relationship benefits, satisfaction, trust, commitment and loyalty for novice and experienced service users. European Journal of Marketing, 44(9/10), 1528-1552.

Doney, P. M., \& Cannon, J. P. (1997). An examination of the nature of trust in buyer-seller relationships. Journal of Marketing, 61(2), 35-51. http://dx.doi.org/10.2307/1251829

Fornell, C., \& Larcker, D. F. (1981). Evaluating structural equation models with unobservable variables and measurement error. Journal of Marketing Research, 18(1), 39-50. http://dx.doi.org/10.2307/1251829

Gaynor, M. (1994). Issues in the industrial organization of the market for physician services. Journal of Economics \& Management Strategy, 3(1), 211-255. http://dx.doi.org/10.1111/j.1430-9134.1994.00211.x

Grönroos, C. (1997). Value-driven relationship marketing: From products to resources and competencies. Journal of Marketing Management, 13(5), 407-419.

Gwinner, K. P., Gremier, D. D., \& Bitner, M. J. (1998). Relational benefits in services industries: The customer's perspective. Journal of the Academy of Marketing Science, 26(2), 101-114. http://dx.doi.org/10.1177/0092070398262002

Hair, J., Black, W., Babin, B., Anderson, R., \& Tatham, R. (2006). Multivariate data analysis. Uppersaddle River, N.J.: Pearson Prentice Hall.

Hazan, C., \& Shaver, P. (1987). Romantic love conceptualized as an attachment 
process. Journal of Personality and Social Psychology, 52(3), 511-24. http://dx.doi.org/10.1037/0022-3514.52.3.511

Hennig-Thurau, T., Gwinner, K. P., \& Gremler, D. D. (2002). Understanding relationship marketing outcomes: An integration of relational benefits and relationship quality. Journal of Service Research, 4(3), 230-247. http://dx.doi.org/10.1177/1094670502004003006

Hutchinson, D., Wellington, W. J., Saad, M., \& Cox, P. (2011). Refining value-based differentiation in business relationships: A study of the higher order relationship building blocks that influence behavioral intentions. Industrial Marketing Management, $\quad$ 40(3), 465-478. http://dx.doi.org/10.1016/j.indmarman.2010.08.010

Johnson, J. L. (1999). Strategic integration in industrial distribution channels: Managing the interfirm relationship as a strategic asset. Journal of the Academy of Marketing Science, 27(1), 4-18. http://dx.doi.org/10.1177/0092070399271001

Kotler, P. (2012). Kotler on marketing. New York, NY: The Free Press.

Lagace, R. R., Dahlstrom, R., \& Gassenheimer, J. B. (1991). The relevance of ethical salesperson behavior on relationship quality: The pharmaceutical industry. Journal of Personal Selling \& Sales Management, 11(4), 39-47.

Mende, M., \& Bolton, R. N. (2011). Why attachment security matters: How customers' attachment styles influence their relationships with service firms and service employees. Journal of Service Research, 14(3), 285-301. http://dx.doi.org/10.1177/1094670511411173

Mende, M., Bolton, R. N., \& Bitner, M. J. (2013). Decoding customer-firm relationships: How attachment styles help explain customers' preferences for closeness, repurchase intentions, and changes in relationship breadth. Journal of Marketing Research, 50(1), 125-142. http://dx.doi.org/10.1509/jmr.10.0072

Morgan, R. M., \& Hunt, S. D. (1994). The commitment-trust theory of relationship marketing. Journal of $\quad$ Marketing, 58(3), 20-38. http://dx.doi.org/10.2307/1252308

Nath, P., \& Mukherjee, A. (2012). Complementary effects of relational bonds in information asymmetry contexts. Journal of Services Marketing, 26(3), 168-180. http://dx.doi.org/10.1108/08876041211223979

Naudé, P., \& Buttle, F. (2000). Assessing relationship quality. Industrial Marketing Management, 29(4), 351-361.

Oliver, R. L. (2014). Satisfaction: A behavioral perspective on the consumer. New York, NY: Routledge. 
Palmatier, R. W., Gopalakrishna, S., \& Houston, M. B. (2006). Returns on business-to-business relationship marketing investments: Strategies for leveraging profits. Marketing Science, 25(5), 477-493. http://dx.doi.org/10.1287/mksc.1060.0209

Palmatier, R. W., Scheer, L. K., Houston, M. B., Evans, K. R., \& Gopalakrishna, S. (2007). Use of relationship marketing programs in building customer-salesperson and customer-firm relationships: Differential influences on financial outcomes. International Journal of Research in Marketing, 24(3), 210-223.

Parasuraman, A., Zeithaml, V. A., \& Berry, L. L. (1985). A conceptual model of service quality and its implications for future research. Journal of Marketing, 49(4), 41-50. http://dx.doi.org/10.2307/1251430

Park, H., \& Kim, Y. K. (2014). The role of social network websites in the consumer-brand relationship. Journal of Retailing and Consumer Services, 21(4), 460-467.

Paulssen, M. (2009). Attachment orientations in business-to-business relationships. Psychology \& Marketing, 26(6), 507-53. http://dx.doi.org/10.1002/mar.20285

Price, L. L., \& Amould, E. J. (1999). Commercial friendships: Service provider-client relationships in context. Journal of Marketing, 63(4), 38-56. http://dx.doi.org/10.2307/1251973

Rafiq, M., Fulford, H., \& Lu, X. (2013). Building customer loyalty in online retailing: The role of relationship quality. Journal of Marketing Management, 29(3-4), 494-517. http://dx.doi.org/10.1080/0267257X.2012.737356

Reynolds, K. E., \& Beatty, S. E. (1999). Customer benefits and company consequences of customer-salesperson relationship in retailing. Journal of Retailing, 75(1), 11-32. http://dx.doi.org/10.1016/S0022-4359(99)80002-5

Swaminathan, V., Stilley, K. M., \& Ahluwalia, R. (2009). When brand personality matters: The moderating role of attachment styles. Journal of Consumer Research, 35(6), 985-1002. http://dx.doi.org/10.1086/593948

Sweeney, J. G., \& Webb, D. A. (2007). How functional, psychological, and social relationship benefits influence individual and firm commitment to the relationship. Journal of Business \& Industrial Marketing, 22(7), 474-488. http://dx.doi.org/10.1108/08858620710828854

Thomson, M., \& Johnson, A. R. (2006). Marketplace and personal space: Investigating the differential effects of attachment style across relationship $\begin{array}{llll}\text { contexts. Psychology \& } & \text { 711-726. }\end{array}$ http://dx.doi.org/10.1002/mar.20125 
Trinke, S. J., \& Bartholomew, K. (1997). Hierarchies of attachment relationships in young adulthood. Journal of Social and Personal Relationships, 14(5), 603-625. http://dx.doi.org/10.1177/0265407597145002

Tzokas N., \& Saren, M. (1999). Value transformation in relationship marketing. Australasian Marketing Journal, 7(1), 52-62. http://dx.doi.org/10.1016/S1441-3582(99)70202-8

Ulaga, W., \& Eggert, A. (2005). Relationship value in business markets: The construct and its dimensions. Journal of Business-to-Business Marketing, 12(1), 73-99. http://dx.doi.org/10.1300/J033v12n01_04

Verbeke, W., Bagozzi, R. P., \& van den Berg, W. E. (2014). The role of attachment styles in regulating the effects of dopamine on the behavior of salespersons. Frontiers in human neuroscience, $8, \quad 32-36$. http://dx.doi.org/10.3389/fnhum.2014.00032

Woo, K. S., \& Ennew, C. T. (2004). Business-to-business relationship quality: An IMP interaction-based conceptualization and measurement. European Journal of Marketing, 38(9/10), 1252-1271. http://dx.doi.org/10.1108/03090560410548960

Wulf, K. D., Odekerken-Schröder, G., \& Iacobucci, D. (2001). Investments in consumer relationships: A cross-country and cross-industry exploration. Journal of Marketing, 65(4), 33-50. http://dx.doi.org/10.1509/jmkg.65.4.33.18386

Zeithaml, V. A. (1988). Consumer perceptions of price, quality, and value: A means-end model and synthesis of evidence. Journal of Marketing, 52(3), 2-22. http://dx.doi.org/10.2307/1251446 